\title{
Study on separation of phosphate from phosphate ore by flotation
}

\author{
Fengxiang Jiang ${ }^{\mathrm{a}}$, Yanhai Shao ${ }^{\mathrm{b}},{ }^{*}$ Shuan $\mathrm{Xu}^{\mathrm{c}}$ and Mingming $\mathrm{Li}^{\mathrm{d}}$ \\ Kunming University of Science and Technology, Kunming 650093, China \\ achengzhang1025@163.com, bcsusyh@126.com, 'lanhualishi@163.com dLmingming0318@163.c \\ om
}

Keywords: Phosphate ore, Flotation.

\begin{abstract}
According to the properties of low grade phosphate rock, a positive-reverse flotation process is developed as a new way for making good use of phosphate rock and a good quantity of the product is obtained. In this paper the optimum flotation conditions with depressant dosage and collector dosage have been demonstrated. Na2SiO3 as depressant $3.2 \mathrm{~kg} / \mathrm{t}$ and fatty acid as collector $0.44 \mathrm{~kg} / \mathrm{t}$ in the positive flotation, H3PO4 as depressant $4.4 \mathrm{~kg} / \mathrm{t}$ and sodium oleate as collector $0.24 \mathrm{~kg} / \mathrm{t}$ in the reverse flotation, under this condition, we finally got the phosphate concentrate about the grade of $\mathrm{P} 2 \mathrm{O} 5$ is $31.29 \%$, the recovery is $59.17 \%$ and gained a better indicator of dressing.
\end{abstract}

\section{Introduction}

China is abundant in phosphate resources. But the grade of phosphate ore is not high In addition, phosphate ore usually contains high amount of $\mathrm{Mg}$ and $\mathrm{Ca}$, therefore it is hard to separate value minerals from gangue minerals. Recovering phosphate from phosphate ore have three main kinds of mineral processing methods: straight flotation, positive-reverse flotation and double reverse flotation. The most useful method is straight flotation in acidic conditions. Apatite is a valuable resource and $90 \%$ of them are used to produce phosphate fertilizer ${ }^{[1-5]}$.

This article mainly studied about the flotation reagents on positive-reverse flotation of phosphate ore, which aim at increasing the utilization efficiency of phosphate resource.

\section{Materials}

The chemical composition of phosphate ore is shown in table 1 and the mineral analysis of phosphate ore is shown in table 2.

Table 1. The multi element analysis of ore $\%$

\begin{tabular}{lllllllll}
\hline $\mathrm{P}_{2} \mathrm{O}_{5}$ & $\mathrm{CaO}$ & $\mathrm{SiO}_{2}$ & $\mathrm{Al}_{2} \mathrm{O}_{3}$ & $\mathrm{TFe}$ & $\mathrm{MgO}$ & $\mathrm{Na}_{2} \mathrm{O}$ & $\mathrm{K}_{2} \mathrm{O}$ & $\mathrm{TiO}_{2}$ \\
15.21 & 34.39 & 18.28 & 1.02 & 1.31 & 1.13 & 0.059 & 0.96 & 0.15 \\
\hline
\end{tabular}

Table 2. The mineral analysis of ore

\begin{tabular}{lllccccc}
\hline Mineral & Apatite & Dolomite & Calcite & Quartz & Pyrite & Hematite & others \\
Wt $/ \%$ & $35-40$ & $38-43$ & 5 & 15 & $1-2$ & 3 & 2 \\
\hline
\end{tabular}

As observed from table 1 and table 2, apatite is the valuable mineral. The main gangue minerals are dolomite and quartz, which is difficult to separate. So positive-reversed flotation was used in the experiment. Positive flotation is used to separate apatite with quartz and reverse flotation is used to separate apatite with dolomite.

\section{Positive flotation experiments}

The flow chart of positive flotation is shown in Fig 1. 


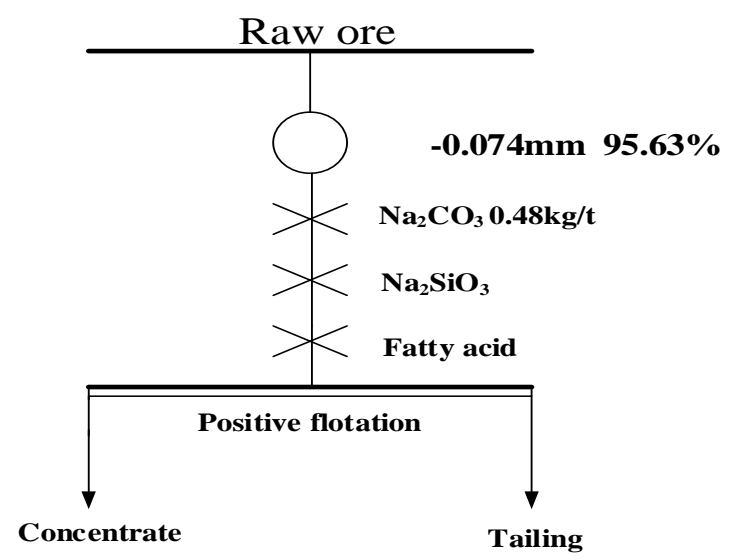

\section{$\mathrm{Na}_{2} \mathrm{SiO}_{3}$ dosage}

Fig. 1. The flow chart of positive flotation.

$\mathrm{Na}_{2} \mathrm{SiO}_{3}$ is the depressant used in the positive flotation. $\mathrm{Na}_{2} \mathrm{CO}_{3}$ is the $\mathrm{pH}$ regulator. $\mathrm{pH}$ of the solution is adjusted to about 9.5 and the dosage of $\mathrm{Na}_{2} \mathrm{CO}_{3}$ is $4.8 \mathrm{~kg} / \mathrm{t}$. Fatty acid is the collector of apatite and amount of fatty acid was fixed at $0.32 \mathrm{~kg} / \mathrm{t}$. Separation Efficiency is defined as: $\mathrm{E}=$ Recovery(\%) - Yield(\%). The effect of $\mathrm{Na}_{2} \mathrm{SiO}_{3}$ dosage was researched and the result is shown in Table 3.

Table 3. The effect of Na2SiO3 dosage

\begin{tabular}{lllll}
\hline Amount $(\mathrm{kg} / \mathrm{t})$ & Yield(\%) & $\mathrm{P}_{2} \mathrm{O}_{5}(\%)$ & Recovery(\%) & $\mathrm{E}$ \\
\hline 2.0 & 74.50 & 16.64 & 75.96 & 1.46 \\
3.2 & 72.59 & 16.96 & 75.43 & 2.84 \\
4.4 & 66.98 & 16.89 & 69.32 & 2.34 \\
5.6 & 66.63 & 16.79 & 68.93 & 2.30 \\
\hline
\end{tabular}

As observed from table 3, with the increasing of $\mathrm{Na}_{2} \mathrm{SiO}_{3}$ dosage, $\mathrm{E}$ increases first and then decreases. When the dosage of $\mathrm{Na}_{2} \mathrm{SiO}_{3}$ is $3.2 \mathrm{~kg} / \mathrm{t}$, separation efficiency reach to the best. When the dosage of $\mathrm{Na}_{2} \mathrm{SiO}_{3}$ is more than $3.2 \mathrm{~kg} / \mathrm{t}$, the content of $\mathrm{P}_{2} \mathrm{O}_{5}$ changes very little but recovery of $\mathrm{P}_{2} \mathrm{O}_{5}$ decreases. Comprehensive consideration, the optimal $\mathrm{Na}_{2} \mathrm{SiO}_{3}$ dosage is $3.2 \mathrm{~kg} / \mathrm{t}$.

\section{Collector dosage}

For the recovery of apatite from phosphate ore by positive flotation, fatty acid is the effective collector of apatite. Reasonable collector dosage can separate apatite from quartz effectively. $\mathrm{Na}_{2} \mathrm{CO}_{3}$ is the $\mathrm{pH}$ regulator. $\mathrm{pH}$ of the solution is adjusted to about 9.5 and the dosage of $\mathrm{Na}_{2} \mathrm{CO}_{3}$ is $4.8 \mathrm{~kg} / \mathrm{t} . \mathrm{Na}_{2} \mathrm{SiO}_{3}$ is the depressants of silicate minerals and amount of $\mathrm{Na}_{2} \mathrm{SiO}_{3}$ was fixed at $3.2 \mathrm{~kg} / \mathrm{t}$. The effect of fatty acid dosage was researched and the result is shown in table 4 .

Table 4 . The effect of fatty acid dosage

\begin{tabular}{lllll}
\hline Amount $(\mathrm{kg} / \mathrm{t})$ & Yield(\%) & $\mathrm{P}_{2} \mathrm{O}_{5}(\%)$ & Recovery(\%) & $\mathrm{E}$ \\
\hline 0.20 & 52.68 & 16.79 & 54.20 & 1.52 \\
0.32 & 72.59 & 16.96 & 75.43 & 2.84 \\
0.44 & 80.17 & 17.20 & 86.48 & 6.31 \\
0.56 & 78.75 & 17.22 & 84.50 & 5.75 \\
\hline
\end{tabular}

As observed from table 4, $\mathrm{E}$ and recovery of $\mathrm{P}_{2} \mathrm{O}_{5}$ increase first and then decrease as the dosage of fatty acid is increasing. The content of $\mathrm{P}_{2} \mathrm{O}_{5}$ is increasing with the dosage of fatty acid increasing. Considering, the content of $\mathrm{P}_{2} \mathrm{O}_{5}$ is qualified and try to improve the recovery of $\mathrm{P}_{2} \mathrm{O}_{5}$, the optimal fatty acid dosage is $0.44 \mathrm{~kg} / \mathrm{t}$.

\section{Reverse flotation experiments}

The flow chart of reverse flotation is shown in Fig 2. 


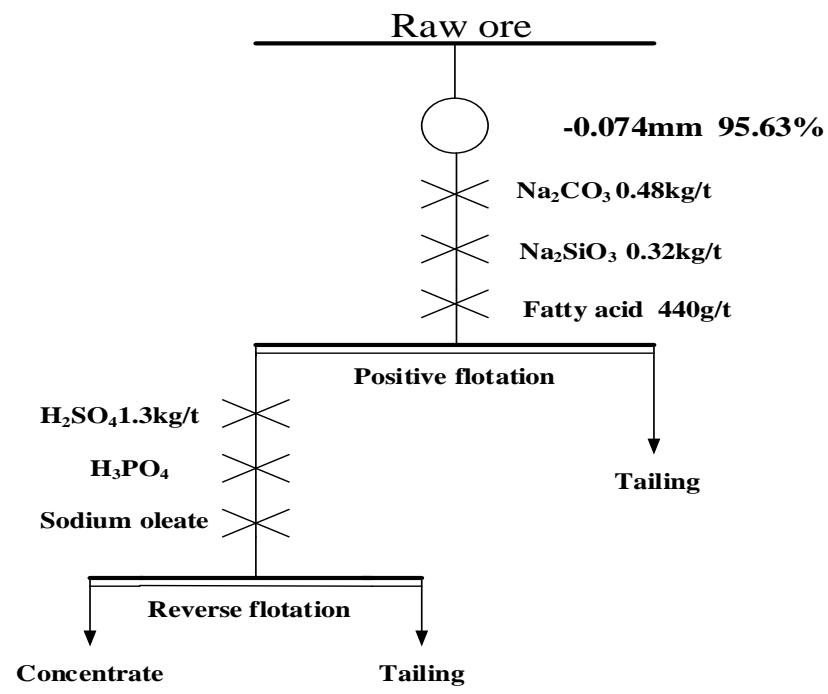

\section{$\mathrm{H}_{3} \mathrm{PO}_{4}$ dosage}

Fig. 2. The flow chart of reverse flotation.

Recovering apatite from phosphate ore by reverse flotation, $\mathrm{H}_{3} \mathrm{PO}_{4}$ is the depressants used in this experiment. $\mathrm{H}_{2} \mathrm{SO}_{4}$ is the $\mathrm{pH}$ regulator, $\mathrm{pH}$ of the solution is adjusted to about 5.4 and the dosage of $\mathrm{H}_{2} \mathrm{SO}_{4}$ is $1.3 \mathrm{~kg} / \mathrm{t}$. Sodium oleate is the collector of Carbonate minerals in the concentration of flotation and amount of sodium oleate was fixed at $0.24 \mathrm{~kg} / \mathrm{t}$. The effect of $\mathrm{H}_{3} \mathrm{PO}_{4}$ dosage was researched, the result is shown in Table 5.

Table 5. The effect of H3PO4 dosage

\begin{tabular}{lllll}
\hline Amount $(\mathrm{kg} / \mathrm{t})$ & Yield(\%) & $\mathrm{P}_{2} \mathrm{O}_{5}(\%)$ & Recovery(\%) & $\mathrm{E}$ \\
\hline 2.0 & 24.07 & 28.77 & 41.74 & 17.67 \\
3.2 & 27.59 & 29.20 & 48.67 & 21.08 \\
4.4 & 28.22 & 31.41 & 53.51 & 25.29 \\
5.6 & 27.90 & 31.18 & 52.50 & 24.60 \\
\hline
\end{tabular}

As can be seen from table 5, when the dosage of $\mathrm{H}_{3} \mathrm{PO}_{4}$ is $4.4 \mathrm{~kg} / \mathrm{t}$, the grade of $\mathrm{P}_{2} \mathrm{O}_{5}$, recovery of $\mathrm{P}_{2} \mathrm{O}_{5}$ and $\mathrm{E}$ are better than the others. The optimal $\mathrm{H}_{3} \mathrm{PO}_{4}$ dosage is $4.4 \mathrm{~kg} / \mathrm{t}$.

\section{Collector dosage}

Recovering apatite from phosphate ore by reverse flotation, sodium oleate is the effective collector of carbonate minerals in the concentration of flotation. Reasonable collector dosage can make apatite effectively separate with carbonate minerals. $\mathrm{H}_{2} \mathrm{SO}_{4}$ is the $\mathrm{pH}$ regulator, $\mathrm{pH}$ of the solution is adjusted to about 5.4 and the dosage of $\mathrm{H}_{2} \mathrm{SO}_{4}$ is $1.3 \mathrm{~kg} / \mathrm{t} . \mathrm{H}_{3} \mathrm{PO}_{4}$ is the effective depressants and amount of $\mathrm{H}_{3} \mathrm{PO}_{4}$ was fixed at $4.4 \mathrm{~kg} / \mathrm{t}$. The effect of sodium oleate dosage was researched and the result is shown in table 6.

As observed from table 6, the $\mathrm{P}_{2} \mathrm{O}_{5}$ content increase as the dosage of sodium oleate increase from 0.08 to $0.40 \mathrm{~kg} / \mathrm{t}$. E and the yield are decreasing with the dosage of sodium oleate increasing. Considering the reagent cost and mineral processing index, the optimal sodium oleate dosage is $0.24 \mathrm{~kg} / \mathrm{t}$.

Table 6. The effect of sodium oleate dosage

\begin{tabular}{lllcl}
\hline Amount $(\mathrm{kg} / \mathrm{t})$ & Yield(\%) & $\mathrm{P}_{2} \mathrm{O}_{5}(\%)$ & Recovery(\%) & $\mathrm{E}$ \\
\hline 0.08 & 39.36 & 27.36 & 65.46 & 26.10 \\
0.16 & 30.95 & 28.92 & 54.18 & 23.23 \\
0.24 & 27.59 & 29.20 & 48.67 & 21.08 \\
0.32 & 27.04 & 29.17 & 47.64 & 20.60 \\
0.40 & 20.79 & 30.63 & 38.20 & 17.41 \\
\hline
\end{tabular}




\section{Optimal experiment}

According to the above experimental study, $\mathrm{Na}_{2} \mathrm{CO}_{3}$ is the $\mathrm{pH}$ regulator, $\mathrm{pH}$ of the solution is adjusted to about 9.5 and the dosage of $\mathrm{Na}_{2} \mathrm{CO}_{3}$ is $4.8 \mathrm{~kg} / \mathrm{t} . \mathrm{Na}_{2} \mathrm{SiO}_{3}$ is the depressant of silicate minerals and amount of $\mathrm{Na}_{2} \mathrm{SiO}_{3}$ was fixed at $3.2 \mathrm{~kg} / \mathrm{t}$. Fatty acid is the effective collector of apatite and amount of fatty acid was fixed at $0.44 \mathrm{~kg} / \mathrm{t} . \mathrm{H}_{2} \mathrm{SO}_{4}$ is the $\mathrm{pH}$ regulator, $\mathrm{pH}$ of the solution is adjusted to about 5.4 and the dosage of $\mathrm{H}_{2} \mathrm{SO}_{4}$ is $1.3 \mathrm{~kg} / \mathrm{t}$. $\mathrm{H}_{3} \mathrm{PO}_{4}$ is the effective depressants in the concentration of flotation and amount of $\mathrm{H}_{3} \mathrm{PO}_{4}$ was fixed at $4.4 \mathrm{~kg} / \mathrm{t}$. Sodium oleate is the effective collector of carbonate minerals in the concentration of flotation and amount of sodium oleate was fixed at $0.24 \mathrm{~kg} / \mathrm{t}$. The result of optimal experiment is shown in table 7.

Table 7. The result of optimal experiment

\begin{tabular}{llcl}
\hline Yield(\%) & $\mathrm{P}_{2} \mathrm{O}_{5}(\%)$ & Recovery(\%) & $\mathrm{E}$ \\
\hline 29.87 & 31.29 & 59.17 & 29.3 \\
\hline
\end{tabular}

\section{Conclusion}

Positive-reverse flotation was adapted to recovery phosphate from phosphate ore. $\mathrm{Na}_{2} \mathrm{SiO}_{3}$ as depressant $3.2 \mathrm{~kg} / \mathrm{t}$ and fatty acid as collector $0.44 \mathrm{~kg} / \mathrm{t}$ in the positive flotation, $\mathrm{H}_{3} \mathrm{PO}_{4}$ as depressant $4.4 \mathrm{~kg} / \mathrm{t}$ and sodium oleate as collector $0.24 \mathrm{~kg} / \mathrm{t}$ in the reverse flotation, in these conditions, a fine quality phosphate concentrate was obtained, the grade of $\mathrm{P}_{2} \mathrm{O}_{5}$ is $31.29 \%$, the recovery of phosphate is $59.17 \%$ and the yield of phosphate is $29.87 \%$.

\section{Reference}

[1] U.S.Geological Survey.Mineral Commodity Summaeies[EB/OL],2003,(1):24-26

[2] Robert Bruee.Flotation of Wolframite.Sei[J].Tefre.Mem, 1965,(7):95-97

[3] Stefanovskaya L.K.New Collecting Reagent for Dressing Lean Phosphate Ores[J].Pererab Okislermykh Rud,1985.

[4] Mingming L,Yanhai S,Shuan X.Study on mineral processing technology of coal pyrite in Yunnan. Appl Mech Mater 2014;522-524:1480-1483

[5] Abdel-Zaher M.Abouzeid.PhysicaJ and thermal treatment of phosphate ores.An overview. Int. J. Miner. Process.2008:59-84. 